\title{
Investigating the Sixth Semester Students' Knowledge of Speech Act: A Collective Response from EFL students of Class B at University of Islam Malang
}

\section{Achmad Kholili ${ }^{1}$}

\author{
* Correspondence: \\ achmadkholili93@gmail.com ${ }^{1}$ Faculty \\ of Teacher Training and Education, \\ University of Islam Malang, East Java, \\ Indonesia
}

Received: 11 July 2018

Revision: 3 August 2018

Accepted: 23 September 2018

Published online: 20 December 2018

\begin{abstract}
An utterance may constitute act. Hence, performing acts through speech are commonly committed by people currently; it is no exception for the EFL students. Some linguists assert that learning communicative competence is of great importance in communication including the act of speaking in the social context. This study was carried out to investigate the students' acquaintances with speech act. A survey was conducted in this study so as to know their acquaintances with speech act. This study focused on the divisions of speech act including locutionary act, illocutionary act, perlocutionary act, and direct and indirect speech act. The data resource was the sixth semester students of class B at University of Islam Malang majoring in English Education Program. A questionnaire was distributed to know if they have an acquaintance with the speech act. The data was analyzed with descriptive statistics after being collected. The findings revealed that the students still committed errors towards the speech act competence. They, a considerable part, did not know parts of speech act which is salient to recognize. For this reason, the researcher expects that the students will be capable of recognizing more on speech act by learning either from this paper or from other resources regarding speech act learning.
\end{abstract}

Keywords: communicative competence, speech act, EFL students 


\section{Introduction}

In daily life, people are indivisible to communication. Communication exists so as to make our interaction purposive. Kaburise (2005) states that successful communication depends not only on the receivers' reception of the message and their appreciation of the fact that it is intended for them, but also upon hearers' recognizing the senders' communicative intent and making an appropriate behavioral or linguistic response to it. Some people may communicate with a wide range of purposes, for instance, they communicate for business, studying, travelling, etc.

In communication, it is for sure that the speakers should consider the salient parts of communication. They include how to communicate; this is called as discourse competence, the way to communicate including speech act, that is, sociolinguistic competence, and how to deal with communication breakdown, that is, strategic competence. All are included in communicative competence. As what Richard and Schmidt (2010, pp.99) say that communicative competence is the knowledge of not only if something is formally possible in a language, but also whether it is feasible, appropriate, or done in a particular speech community. It includes grammatical competence i.e. knowledge of the grammar, vocabulary, phonology, and semantics of a language. Secondly, sociolinguistics competence, that is, knowing how to use and respond appropriately to different types of speech act. Thirdly, discourse competence, that is, how to begin and end the conversation. Lastly, strategic competence in which it is a knowledge of communication strategies that can compensate for weakness in other areas. All the four aspects are of great importance for us to consider in communication.

From those four aspects, the good, salient thing to discuss is about sociolinguistic competence, that is, speech act. According to Kaburise (2005, pp.113), the act of giving information, performed through speech or words are termed as "speech act" or "speech event." He also states that the term "speech act" is used to refer to the act of speaking or sending spoken or written intention to other members of speech community. From this note, we know that the speech act is an act of uttering word that is meaningful performed through speech. Speech act, in this case, plays a significant role in communication. The speaker must be capable of recognizing the speech act in communication.

The recognition of speech act can be successful if the speaker has known the crucial divisions of speech act including promising, making a request, commanding, etc. Those all are included in speech act. Kaburise (2005) further asserts that the speech act is not one of either uttering a statement, an interrogative, or an imperative, but one of making a request for hearer to decrease the chill factor or increase the hit in a room. It is obvious that speech act has some divisions including a request belonging to indirect speech act. However, based on the information of some students at University of Islam Malang, many of the sixth semester students of class B at University of Islam Malang are not well-recognized with the divisions or parts of speech act even though they probably have ever learnt or have even practiced them in their daily life.

Since this is the case, the researcher is interested in investigating their acquaintances with the speech act. Not only is the researcher motivated by himself to study on the aforementioned topic, but he is also encouraged by philosophers, one of whom is Songkhro. Songkhro (2014) states that language proficiency and pragmatic competence need to be investigated more extensively using different research methodology and a larger sample size.

\subsection{Problems of the Study}

The problem of the research is formulated as follows:

Did the sixth students of class B at University of Islam Malang recognize speech act competence?

\subsection{Objective of the Study}

The study is conducted to know whether the EFL students of University of Islam Malang have recognized the speech act or not.

\subsection{Significance of the Study}

There are two entities who are involved in this case.

\section{For researcher}

The researcher will know that applying and recognizing speech act is very important to do.

2. For respondent 
By conducting this study, it will be important for people to recall the elements of the speech and can reapply to their daily life in communication.

\section{Literature Review}

\subsection{Studies on Speech Act Competence}

If looked at the past time, there were several studies conducted by the linguists with regards to pragmatic knowledge including speech act, some of whom will be stated further in this section. Walters $(2004,2007,2009)$ and Alemi and Khanlarzadeh (2016) criticized the previous speech act theory-based L2 pragmatic tests, and claimed that they raised validity issues due to their lack of compatibility with a conversational data. In this case, Walter focused on conversation analysis in testing pragmatic comprehension, production, compliment responses, and pre-sequences responses of language learners through role plays, DCTs, and listening comprehension.

In the meantime, Cohen (2014) and Alemi and Khanlarzadeh (2016) stressed the necessity of considering several important factors in assessing pragmatic competence. He suggested strategies such as using realistic situations, checking different features of the performance, asking the students to compare their responses with native speakers, asking students to explain their rationales for their answers, and being strategic in assessing various aspects of speech acts. Furthermore, Alemi and Khanlarzadeh (2016) investigated native and non-native rater's rating criteria regarding the assessment of EFL learners' production of the refusal speech act. Their analysis of raters' comments revealed six criteria: "politeness", "brief apology", "irrelevancy of speech act", postponing to another time", "explanation" and "statement of alternative."

Another study was also conducted recently (Songkhro, 2014). His findings revealed that the participants had certain capability of performing appropriate speech act in the given scenarios, but not at a highly successful communication level. He suggested that to help students successfully master English and survival well in international and intercultural communication, the teachers should raise their awareness on how to use target language appropriately when in contact with English language speakers and identify the differences between the norms of the students' mother tongue and those of the target language along with linguistic language.

According to Richard and Schmidt (2010, pp.542), in dictionary of Language Teaching and Applied linguistics, speech act is defined as an utterance of functional unit in communication. In speech act theory, utterances have two kinds of meaning: (a) Prepositional meaning (also known as Locutionary Meaning). This is the basic literal meaning of the utterance which is conveyed by the particular words and structures which the utterance contains Proposition and Locutionary Act. (b) Illocutionary meaning (is also known as illocutionary force). This is the effect the utterance or written text has on the reader or listener.

\subsection{Austin's Speech Act Theory}

Another expert investigating the use of language, that is, Austin has classified the speech act into some categories: explicit performative and implicit performative. Austin (1975) and Seken (2015) distinguishes explicit performative from implicit performative, the former being ones that characteristically begin with an expression such as "I promise." The latter, on the other hand, which they preferably call primary performative can be found in utterance such as "I shall be there."

Comparing primary and explicit performative:

(1) Primary utterance: "I shall be there"

(2) Explicit performative: "I promise that I shall be there"

Austin explains that "the latter formula made explicit what action it is that is being performed in issuing the utterance: i.e. I shall be there" whereas the utterance "I shall be there" without "I promise that" may not clearly and automatically be taken as a promise, that is, it may have an ambiguous reading. In the meantime, Austin also determines speech act into three categories: Locutionary Act, Illocutionary Act, and Perlocutionary Act. Locutionary act is the act of producing meaningful sounds, i.e. the production of word with meanings. Illocutionary act is the act of issuing an utterance with a particular force such as "ordering" and "promising"; it is conventional communicative force "in saying.' Perlocutionary act is the actual effect achieved 'by saying.' 
According to Kaburise (2005), locutionary act is a complex act comprising several types of actions: phonological, syntactic and semantic, hence it is the uttering of a sentence with determinate sense and reference (the actual words uttered). Illocutionary act is what is usually meant when we make an utterance is that we accomplish some specific social act, for example, the making of a statement, an offer, or a promise, by a virtue of the conventional force associated with it. Perlocutionary act is the bringing about of effects on the audience by means of uttering the sentence, such effect being special to the circumstance of utterance (the effect of illocution on the hearer).

On the basis of their illucotionary force, Austin (1975) and Seken (2015) roughly classify utterances into five classes, namely: "Verdictives', "Exercitives", "Commissive", 'Behabitives", and "Expositives."

Verdictives are utterances whose force is characterized by "the giving of verdict... by a jury, arbitrator, or umpire.

Exercitives are characterized by "the exercising of powers, rights, or influence.

Commissives are utterances which commit the speaker to doing something, such as in promising.

Behabitives have to do with "attitudes" and "social behavior" such as in apologizing and congratulating.

Expositives: which Austin finds difficult to define, are described as those that "make plain how our utterances fit into the course of an argument or conversation, how we are using words, or, in general, are expository.

Verdictives: Exercising a judgment: acquitting, assessing, analyzing

Exercitives: assertion of influence in favor of against a certain course of action: ordering, commanding.

Commisives: Assuming an obligation, committing the speaker to a certain course of action: promising

Behabitives: Adopting an attitude: thanking, deploring

Expositives: Expounding a view, clarifying reason: stating, replying, conceding.

\subsection{Searle's Speech Act Theory}

Not only Austin' speech act theory plays an important role in communicative competence, but Searle's speech act theory also does. Schiffrin (1994) and Seken (2015) observe that Searle's ideas are significant in that they make it possible for the speech act to be applied in discourse studies. According to Searle (1969) and Seken (2015), the smallest unit of linguistic communication is speech act. Searle sees language as a rule-governed intentional behavior and maintains that speaking a language is performing speech act which means that it is performed in accordance with certain rules for the use of linguistic elements.

Like Austin, Searle identifies three aspects of speech acts, which he refers to as, respectively, "utterance acts, propositional acts, and illocutionary acts. Utterance act refers to "Uttering string of words" which is related to the production of literal meaning and reference. Searle asserts that illocutionary and propositional acts consist of characteristically in uttering words in sentences in certain contexts, under certain conditions and with certain intention." Seale said that in performing illocutionary act one characteristically performs propositional and illocutionary acts on the other like the relation which "making an "X" on a ballot paper stands to voting."

In Searle's' ideas, he maintains that the ideas of illocutionary acts correlate to the notion of the consequences of effects. Such acts bring about on the hearer's actions, thoughts, and beliefs. The relation between prepositional acts and illocutionary acts is, according to Seale, a typical one. "Prepositional acts cannot occur alone", they must therefore be part of an act which counts as "whole." Seen in this way, prepositional acts are in fact parts of illocutionary acts. "When a proposition is expressed it is always expressed in the performance of an illocutionary acts" (Searle, 1960, pp. 29), while the expression of a proposition is a propositional act" (Searle, 1969; Seken, 2015).

\subsection{Direct and Indirect Speech Act}

In addition to the Austin and Searle's theories of speech act, Direct and Indirect speech act are included in this paper. The writer knows that very often the speaker says something to us. We know that how the speaker intends to us to take the function of what is said. What the speaker says is quite similar to giving an action. According to Yule (2010, pp.133), we use the term "speech act" to describe actions such as "requesting", "commanding", "questioning", or "informing." We can define speech act as "action" performed by the speaker with utterances. 
For example, you say "I'll be your house at 3 o'clock", it means that you are not only speaking or saying something, but you are performing the speech act of "promising." In this case, the speech act consists of direct and indirect speech act.

When the speaker does not know something, and he/she then asks about it to someone to provide information concerning it using an interrogative structure such as Did you...? Are they...? Or Can you...? , it is described as speech act. For example, did you eat the Bakso? This question belongs to direct speech act.

The following examples are from Yule's book (2010:134),

$\begin{array}{lll} & \text { Structures } & \text { Functions } \\ \text { Did you eat the pizza? } & \text { Interrogative } & \text { Question } \\ \text { Eat the pizza (please)! } & \text { Imperative } & \text { Command (Request) } \\ \text { You eat the pizza. } & \text { Declarative } & \text { Statement }\end{array}$

Compare with the following example: When speaker asks something using "Can you cut my hair?" In this case, the speaker does not normally use this structure as a question at all. He/she normally uses it to make a request. This may use a syntactic structure associated with the function of a question, but in this respect with the function of a request. Another example, that is, "can you pass the salt?" in this example, the speaker is using a syntactic structure associated with the function of a question, but in this case with the function of a request (Yule, 2010, pp.134).

Yule (2010) cites that whenever one of the structures in the set above is used to perform a function other than the one listed beside it on the same line, the result is an indirect speech act. If you say this to someone who has just come in (and it's really cold outside), you would probably want that person to close the door. You are not using the imperative structure. You are using a declarative structure to make a request. It's another example of an indirect speech act (Yule, 2010).

If one fails to recognize another person's indirect speech act. Consider the following example:

Visitor: do you know where the Museum Angkut is?

Passer by: of course. I know where it is.

In this scene, the visitor uses a form associated with a question (Do you know...), and the passer-by answers that question $(I$ know....). That is, the passer-by is acting as if the utterance was a direct speech act instead of an indirect speech act used as a request for direction.

\section{Methodology}

This study uses a descriptive quantitative research, the so-called survey. According to Latief (2016), survey research is typically used to describe opinions, attitudes, preferences, and perceptions of people of interest to the researcher. The population involved is usually large so that random sampling technique is required. In the meantime, Denscombe (2010, pp. 06) points out that the term "survey" means 'to view comprehensively and in detail.' In another sense, it refers specifically to the act of 'obtaining data for mapping.' The researcher uses a survey in purpose to know the students' response to speech act theories.

\subsection{Focuses of the Study}

The determination of the study has two aims. First, focus of the setting of the study, that is, the University of Islam Malang, particularly at the sixth semester of the students of class B at University of Islam Malang. Second, this study focuses on the divisions or parts of speech act which have been set out by Austin and Searle's ideas towards speech act as well as in Yule's book. It includes Locutionary Act, Illocutionary Act, Perlocutionary Act, and Direct and Indirect Speech Act.

\subsection{Data Resource}

The data resource is the sixth semester of students of class b of University of Islam Malang. The data resource is done with simple random sampling. Initially, the population consisted of 30 students, the researcher then decided to choose randomly by giving a number to every member. So, all members had an equal chance of being participants in this 
study. However, out of 30, only 15 students were taken out for being respondents in this study. Hence, 15 students of the sixth semester students of class b at University of Islam Malang constituted the sample of the study.

\subsection{Data Collection}

The data were collected with the exit-questionnaire which contains multiple choice tests that the students must complete it. The questionnaire contains the questions regarding the parts of speech act. The students, in this case, need to choose one of the divisions of speech which best suits to the underlined sentence provided in the questionnaire. The researcher collected the data by coming in the class of the sixth students of class B at University of Islam Malang.

\subsection{Data Analysis}

The data of this study were presented descriptively. In the meantime, due to the fact that this study not only involves a description but a quantity as well, the statistic is used in this study to analyze the data.

\section{Findings}

There are several questions that have been distributed to the students to know their acquaintance with speech act. The questions contain the topic of speech act related to the division of speech act including locutionary act, illocutionary act, perlocutionary act, and direct and indirect speech act. The participants of this question initially consisted of 30 students, but are then chosen randomly becoming 15 students. They all are from the sixth semester students of class $b$ University of Islam Malang of S1 degree. The following is the students' answering results on speech act.

The questions on perlocutionary act:

1. The speaker said, "Please keep this knife away!!!", and then the second speaker answered it "Okav, I'll do it." The underlined sentence belongs to...
a. Illocutionary act
b. Perlocutionary act
c. Indirect speech act
d. Locutionary act

From this question, there are 8 students who answered that question correctly. Those are as follows:

1. Adburrahman

2. Selly

3. LailatulNazimah

4. Ike LailatulIstiqamah

5. MsDhuha

6. ShotwahirRahamahAwaliyah

7. Nasuha

8. Monica Ovi N

The subsequent question related to direct speech act:

2. "Do you know where the Unisma is?" What does the underlined sentence belong to?
a. Illocutionary act
b. Perlocutionary act
c. Direct speech act
d. Indirect speech act

From this question, the researcher found similar number of results to the questions in 1 . The students who answered this question were only 8 out of 15 students which are similar to the previous one. 

1. Ahmad Mujtahid
2. Abdurrahman
3. LailatulNazimah
4. MsDhuha
5. Nuke Arditatus
6. ShotwahirRahmahAwwaliyah
7. Nasuha
8. Ade AriskaDewi

The third question is in keeping with indirect speech act:

3. A: "Do you know where the Batu City is?"

B: Sure, "I know where it is." The underlined sentence belongs to...
a. Perlocutionary act
b. Illocutinary act
c. Locutionary act

d. Indirect speech act

From this question, researcher did not find at all the students answering this question correctly. The result demonstrated zero (none of the students answered the third question correctly).

The fourth question is with respect to illocutionary act.

4. "I will be at the school tomorrow." What does the underlined sentence belong to?
a. Illocutionary act
b. Locutionary act
c. Perlocutionary act
d. Ordering

From this question, the researcher found only five students who answered this question correctly.

1. Selly

2. Abdul Jalil

3. ShotwahirRahmahAwwaliyah

4. Nasuha

5. Ade AriskaDewi

The last question is pertinent to Locutionary act:

5. “It's cold in here." What does the underlined sentence belong to?

\section{a. Locutionary act}
b. Illocutionary act
c. Perlocutionary act
d. Utterance 
From this question, the researcher found similar number to the former question. The students answering that question correctly only consisted of five students.

1. Abdurrahman

2. Lailatulnazimah

3. MsDhuha

4. SitiSifaiyah

5. Monica Ovi N

\section{Discussion}

Since it is found that there still have been some errors committed by the sixth semester students of class B at University of Islam Malang concerning speech act learning, the answers of the students will be discussed as follows according to some theory:

1. The speaker said, "Please keep this knife away!!!", and then the second speaker answered it "Okav, I'll do it." The underlined sentence belongs to...

a. Illocutionary act

b. Perlocutionary act

c. Indirect speech act

d. Locutionary act

According to the Austin (1975 as cited in Seken (2015), perlocutionary act is the actual effect achieved by saying. Whereas, according to Kaburise (2005), perlocutionary act is the bringing about of effects on the audience by means of uttering the sentence, such effect being special to the circumstance of utterance (the effect of the illocution on the hearer). From the question above, it is found that the conversation between the first and the second speaker uses the speech act including direct speech act and perlocutionary act.

A: "Please keep this knife away!!!” (Direct Speech Act)

B: “Okav, I'll do it" (Perlocutionary Act)

So, the answer to the question above is b. Perlocutionary act.

From this question, there are eight students who answered correctly. It is clear that the students which initially consisted of 15 students, only 8 students who answered the question correctly. While the rest answered incorrectly. There are some reasons why they answered the question incorrectly.

First, the students forgot the speech act theory, and the second, the students could not recognize the speech act divisions due to the fact that they learn automatically about the expression of language, while the recognition of speech act is neglected. Thus, they could not recognize the speech act competence.

2. "Do you know where the Unisma is?" What does the underlined sentence belong to?
a. Illocutionary act
b. Perlocutionary act
c. Direct speech act
d. Indirect speech act

According to Yule (2010), direct speech act belongs to question, command (request), and statement. From the questions above, it is found that the underlined sentence constitutes questions. Therefore, it belongs to direct speech act. Thus, the answer is C. Direct speech act. In this question, the students who answered this question were only 8 out of 15 students. It seems that most of the students still had knowledge of the speech act on this question. Since only 8 students out of 15 who answered the question correctly, the implication is the same, namely, first, the students forgot the divisions of speech act. The second one is that the students have acquisition on their language but the recognition 
of speech act is missed because they only focus on language acquisition not on speech act. Therefore, they could not recognize the speech act competence.

3. A: "Do you know where the Batu City is?"

B: Sure, "I know where it is." The underlined sentence belongs to...
a. Perlocutionary act
b. Illocutinary act
c. Locutionary act

d. Indirect speech act

From this question, researcher did not find at all the students answering this question correctly. The result demonstrated zero (none of the students answered the third question correctly).

Indirect speech act is not like direct speech act. Indirect speech is an implication of the direct speech act. We may take a look at the question above. "I know where it is". The speaker knew the location but he did not cite where the location is. Thus, the answer is D. Indirect speech act. From this question, it was found that all of the students answered this question incorrectly. It implies that the sentence above is only a statement or an act. Instead, that is an indirect speech act. In this question, the students could not answer the question correctly. Almost this question is incorrectly answered by the students. There were few students who recognized this question as perlcoutionary act, other students recognized this question as illocutionary act and locutionary act. It is obvious that the students had no acquaintance with the speech act (indirect speech act). The implication is similar to the previous one. First, the students might have gained the knowledge of speech act in their previous semester but they forgot the knowledge of speech and the second one is that the students, for the most part, learn speech act as an introduction only, so they do not practice it in their daily life. Thus, it made them forget the speech act competence.

4. "I will be at the school tomorrow." What does the underlined sentence belong to?
a. Illocutionary act
b. Locutionary act
c. Perlocutionary act
d. Ordering

From this question, the researcher found only five students who answered this question correctly.
6. Selly
7. Abdul Jalil
8. ShotwahirRahmahAwwaliyah
9. Nasuha
10. Ade AriskaDewi

According to Kaburise (2005), illocutionary act is what is usually meant when we make an utterance is that we accomplish some specific social act, for example, the making of a statement, an offer, or a promise, by virtue of the conventional force associated with it. From the question above, we know that the "I will be at the school tomorrow" is like a promise said by the speaker. Thus, the statement belongs to illocutionary act. As has been stated by Fiorito (2005), illocutionary act is making a statement, offer, promise, etc. In this question, there were 5 out of 15 students who answered the question correctly. The rest of them answered incorrectly. It is clear that few students had knowledge of speech act specifically on illocutionary act, while others are not. The implication is the same: first, the students forgot the speech act even though they might have learnt them before. Second, the students could not recognize the speech act because they did not practice to recognize it in their daily conversation.

5. “It's cold in here." What does the underlined sentence belong to?

\section{a. Locutionary act}


b. Illocutionary act

c. Perlocutionary act

d. Utterance

From this question, the researcher found similar number to the former question. The students answering that question correctly only consisted of 5 students out of 15 .

5. Abdur rahman

6. Lailatul nazimah

7. Ms Dhuha

8. Siti Sifaiyah

9. Monica Ovi N

According to Kaburise (2005), locutionary act is a complex act comprising several types of actions: phonological, syntactic and semantic, hence it is the uttering of a sentence with determinates sense and reference (the actual words uttered). The sentence above is “It's cold in here." Therefore, it belongs to locutionary act because locutionary act is the act of 'saying' a sentence with determinate sense and reference (Fiorito, 2005, pp. 53). In this question, there were also 5 out of 15 students who answered correctly. There were two possibilities when they answered correctly in this question. First, they did not forget the division of speech acts i.e. the locutionary act. The second one is that they might recall it when they communicate. Other students forgot parts of the speech act because they might forget it, or they might not practice it in their daily conversation, so they did not recognize the illocutionary act.

The calculation of the statistic is also done since it is a survey method. With regard to the questionnaire distributed to the students, the questions have a score. Every question consists of 5 questions and therefore it has a score of 20 in one question. If the students answer all the questions correctly, they will gain 100. If the students correctly answer one question only, the score will be 20 because one correct answer to the question is regarded 20 . The following is the result of the survey after being calculated with descriptive statistics.

Table 1. The survey of the students' knowledge of speech act of class b at University of Islam Malang

\begin{tabular}{|c|c|c|c|c|c|c|c|}
\hline No & Nama & Academic Year & Semester & Score & Mean & Std. Deviasi & Sq. Deviasi \\
\hline 1 & Ahmad Mujtahid & $2016 / 2017$ & Odd & 20 & 34.66 & 14.66 & 214.9156 \\
\hline 2 & DytaAryati & $2016 / 2017$ & Odd & 0 & 0 & 0 & 0 \\
\hline 3 & Ilmiyah & $2016 / 2017$ & Odd & 0 & 0 & 0 & 0 \\
\hline 4 & Abdurrahman & $2016 / 2017$ & Odd & 60 & 34.66 & -25.34 & 642.1156 \\
\hline 5 & Selly & $2016 / 2017$ & odd & 40 & 34.66 & -5.34 & 28.5156 \\
\hline 6 & LailatulNazimah & $2016 / 2017$ & odd & 60 & 34.66 & -25.34 & 642.1156 \\
\hline 7 & Ike Lailatul I. & $2016 / 2017$ & odd & 20 & 34.66 & 14.66 & 214.9156 \\
\hline 8 & Abdul jalil & $2016 / 2017$ & odd & 20 & 34.66 & 14.66 & 214.9156 \\
\hline 9 & MsDhuha & $2016 / 2017$ & odd & 60 & 34.66 & -25.34 & 642.1156 \\
\hline 10 & Nuke Arditatus & $2016 / 2017$ & odd & 20 & 34.66 & 14.66 & 214.9156 \\
\hline 11 & ShotwahirRohmah & $2016 / 2017$ & odd & 60 & 34.66 & -25.34 & 642.1156 \\
\hline 12 & Nasuha & $2016 / 2017$ & odd & 60 & 34.66 & -25.34 & 642.1156 \\
\hline 13 & SitiSifaiyah & $2016 / 2017$ & odd & 20 & 34.66 & 14.66 & 214.9156 \\
\hline 14 & Ade Ariskadewi & $2016 / 2017$ & odd & 40 & 34.66 & -5.34 & 28.5156 \\
\hline
\end{tabular}




\begin{tabular}{llllllll}
15 & Monica Ovi N & $2016 / 2017$ & odd & 40 & 34.66 & -5.34 & 28.5156 \\
\hline Total & & 520 & & 4370.7028 \\
\hline
\end{tabular}

$$
\begin{gathered}
s=\sqrt{\frac{\sum(X-\bar{X})^{2}}{n-1}} \\
\sqrt{\frac{\sqrt{4370.7028}}{15-1}} \\
\sqrt{\frac{\sqrt{66.11}}{14}} \\
\sqrt{0.58} \\
=0.76
\end{gathered}
$$

\section{Passing Grade}
$\mathrm{A} \overline{\mathrm{X}}+1.5 \times \mathrm{S}$
B) $\overline{\mathrm{x}}+0.5 \times \mathrm{S}$
C). $\bar{x}-0.5 \times S$
D). $\overline{\mathrm{x}}-1.5 \times \mathrm{S}$
$34.66+1.5 \times 0.76$
$34.66+0.5 \times 0.76$
$34.66-0.5 \times 0.76$
$34.66-1.5 \times 0.76$
$=27.48$
$=26.72$
$=25.96$
$=25.20$

Table 2. The criteria of students' scores

\begin{tabular}{lll}
\hline Criteria & Ranging & Students \\
\hline Very good & $>27.48$ & 8 \\
Good & $26.72---27.48$ & 0 \\
Middle/Enough & $25.96---26.72$ & 0 \\
Bad & $25.20---25.96$ & 0 \\
Very bad & $<25.20$ & 5 \\
\hline
\end{tabular}

Percentage of Students' Scores:
A. $8 / 15 \times 100 \%=53 \%$
B. $0 / 15 \times 100 \%=0 \%$
C. $0 / 15 \times 100 \%=0 \%$
D. $0 / 15 \times 100 \%=0 \%$
E. $5 / 15 \times 100 \%=33 \%$ 


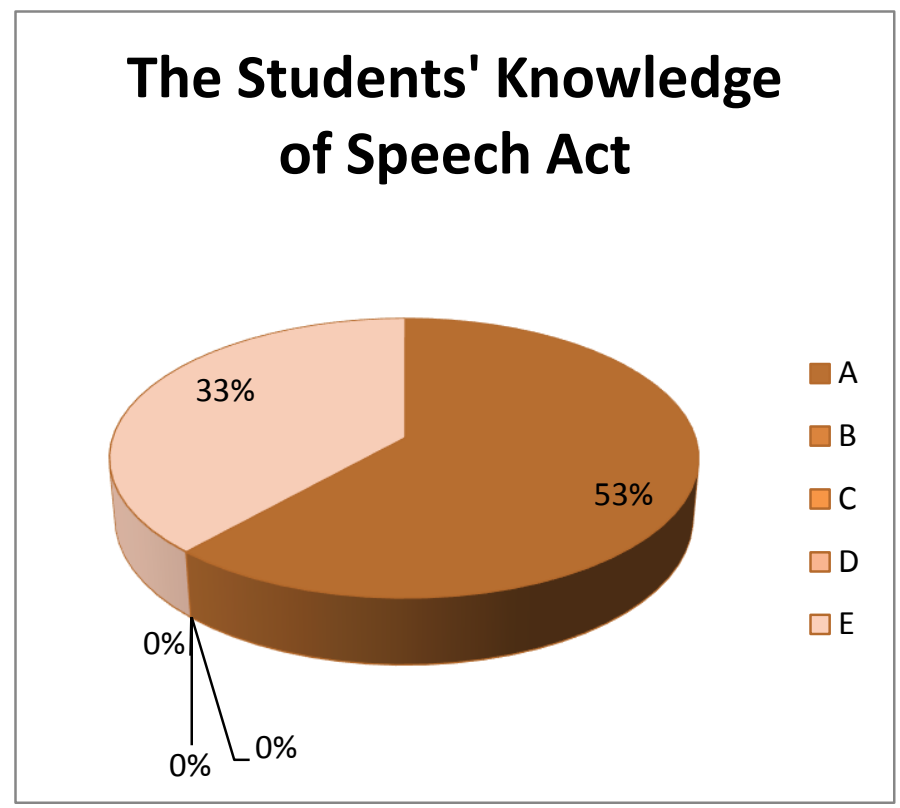

Graph 1. The students' knowledge of speech act

It can be seen from the graph above that the students who gain very good scores are 8 students only (53\%). The students with very low scores are 5 students (33\%). In the meantime, the rest gain zero (0\%).

\section{Conclusion}

After the study was conducted, the writer might draw a conclusion that the sixth semester students of class B at University of Islam Malang did not have much knowledge of speech act. It was based on the discussion and the statistics presented previously. The students committed errors on speech act because of several reasons. First, they forgot the speech act competence even though they might have learnt it before in their previous semester. Second, the students rarely practiced to recognize the divisions of speech act so they did not recognize the speech act competence. As a result, they committed errors in choosing correct answer on the speech act questions. These two things might influence the students' recognition with speech act competence. Therefore, most of the students were failed in recognizing the speech act competence. Since this is the case, further studies on speech act is still of essential to be conducted by other researchers to investigate other students or people concerning speech act learning. It is important to know the speech act competence due to not only the availability of speech act, but is also salient to learn and recognize the speech act because it is used in daily communication. When the speakers are good at speech act, it means that they are successful in communication. If the speakers do not recognize the speech act, it means that they fail in communication and it will result in poor communication. The students may practice to recognize the elements of speech act with their friends in communication.

\section{References}

Alemi, M., \& Khanlarzadeh, N. (2016). Pragmatic assessment of request speech act of Iranian EFL learners by nonnative English speaking teachers. Iranian Journal of Language Teaching Research, 4(2), 19-34. https://files.eric.ed.gov/fulltext/EJ1127421.pdf

Austin, J. L. (1975). How to do things with words (Vol. 1955): Oxford University Press. https://pure.mpg.de/rest/items/item_2271128/component/file_2271430/content

Cohen, A. D. (2014). Towards increased classroom assessment of pragmatic ability. Iranian Journal of Language Testing, 4(1), 4-25. http://ijlt.ir/journal/images/PDF/420-2014-4-1.pdf

Denscombe, M. (2010). The good research guides (2 ${ }^{\text {nd }}$ Ed.). Philadelphia: Open University Press. 
Fiorito, L. (2005). Speech acts and languages for special purposes. Metalogicon, 18(1), 43-60. web.mclink.it/MI2701/rivista/2005gg/Fiorito05gg.pdf

Kaburise, P. (2005). Speech act theory and communication: A univen study (Unpublished PhD Thesis). University of Pretoria, Pretoria. https://repository.up.ac.za/bitstream/handle/2263/27694/Complete.pdf?sequence=9

Latief, M. A. (2016). Research methods on language learning (An Introduction). Malang: Universitas Negeri Malang Press.

Richard, J., \& Schmidt, R. (2010). Dictionary of Language Teaching and Applied Linguistics ( $4^{\text {th }}$ Ed.). British Library: Pearson Education Limited.

Schiffrin, D. (1994). Approaches to discourse. Oxford: Blackwell. https://ddd.uab.cat/pub/lal/11337397n3/11337397n3p147.pdf

Searle, J. R. (1969). Speech acts. An essay in the philosophy of language. Cambridge: Cambridge University Press. https://www.amazon.com/Speech-Acts-Essay-Philosophy-Language/dp/052109626X

Seken, I. K. (2015). Introduction to pragmatics. Yogyakarta: Graha Ilmu.

Songkhro, J. (2014). Speech act knowledge of Thai university students majoring in tourism industry in southern Thailand. (Unplublished Thesis). Songkla University. kb.psu.ac.th/psukb/hitstream/2010/9465/1/387717.pdf

Walters, F. S. (2004). An application of conversation analysis to the development of a test of second language pragmatic competence. Unpublished doctoral dissertation, University of Illinois at Urbana-Champaign.

Walters, F. S. (2007). A conversation-analytic hermeneutic rating protocol to assess L2 oral pragmatic competence. Language Testing, 24(2), 155-183. doi:10.1177/0265532207076362

Walters, F. S. (2009). A conversation analysis-informed test of L2 aural pragmatic comprehensions. TESOL Quarterly, 43(1), 29-54. doi:10.1002/j.1545-7249.2009.tb00226.x

Yule, G. (2010). The study of language ( $4^{\text {th }}$ Ed.).New York: Cambridge University Press. https://www.amazon.com/Study-Language-Yule-George-Hardcover/dp/B01182M7J0 